\title{
Analisis SWOT bagi Perjanjian Komprehensif dan Progresif Perkongsian Trans-Pasifik (CPTPPA): Kes syarikat unit amanah di Malaysia
}

\author{
Sahudin Saat@ Ma'anam ${ }^{1,2}$, Aisyah Abdul-Rahman ${ }^{1,3}$, Rosmah Mat Isa $^{1}$ \\ ${ }^{1}$ Fakulti Ekonomi dan Pengurusan, Universiti Kebangsaan Malaysia \\ ${ }^{2}$ Wealth Vantage Advisoty Sdn. Bhd. \\ ${ }^{3}$ Institut Islam Hadhari, Universiti Kebangsaan Malaysia
}

Correspondence: Aisyah Abdul-Rahman (email: eychah@ukm.edu.my)

Received: 01 March 2020; Accepted: 15 May 2020; Published: 30 May 2020

\begin{abstract}
Abstrak
Kajian ini bertujuan memahami jangkaan awal ke atas kekuatan, kelemahan, peluang dan ancaman yang dihadapi oleh syarikat Unit Amanah (SUA) di Malaysia yang terlibat dalam Perjanjian Komprehensif dan Progresif bagi Perkongsian Trans Pasifik (CPTPPA) yang telah ditandatangani pada 8 Mac 2018. Oleh kerana CPTPPA akan memberi kesan kepada portfolio aset pelaburan bagi pasaran modal dan pasaran saham, maka SUA perlu membuat persediaan dari segi kekuatan dan kelemahan serta mengenalpasti peluang dan ancaman yang bakal dihadapi. Kajian ini menggunakan kaedah kualitatif melalui temu bual mendalam ke atas pengurus dana. Hasil kajian ini mendapati bahawa SUA perlu menggunakan kekuatan seperti kemahiran analisa pasaran, menghasilkan instrumen kewangan yang menarik, memenuhi permintaan pelabur, dan membuat pelaburan baru merentasi sempadan. Hasil kajian menunjukkan bahawa tiada persediaan yang dilakukan oleh SUA menghadapi CPTPPA disebabkan ketiadaan maklumat terperinci oleh agensi kerajaan. SUA telah mengenal pasti beberapa peluang seperti kenaikan KDNK dan eksport akibat daripada CPTPPA. Antara ancaman yang telah dikenalpasti adalah liberalisasi ke atas pasaran tempatan serta ketiadaan regulasi khusus. Oleh itu, SUAM perlu membuat analisa dan merangka strategi untuk menghadapi CPTPPA.
\end{abstract}

Kata kunci: CPTPPA, Malaysia, Peluang dan Cabaran, Saham Amanah, SWOT, Unit Amanah

\section{SWOT analysis for Comprehensive and Progressive Trans-Pacific Partnership Agreement (CPTPPA): A case of Malaysian unit trust companies}

\begin{abstract}
The study aims to identify the initial expectations of the strengths, weaknesses, opportunities and threats faced by the Malaysian Unit Trust Companies (UTC) involved in the
\end{abstract}


Comprehensive and Progressive for Trans-Pacific Partnership Agreement (CPTPPA) which has been officially signed on 8 March 2018. As the CPTPPA will affect the asset portfolio investment in capital markets and stock markets, then UTC need to prepare in terms of knowing their strengths, weaknesses, opportunities, and threats. This study uses qualitative methods through an in-depth interview on fund managers. The findings found that the UTC should utilise strengths such as market analysis skills and offering attractive new financial instruments across borders. The results show that there is inadequate preparation made by the UTC to confront the CPTPPA due to the lack of detailed information provided by government agencies. UTC have identified several opportunities such as the increase in GDP and exports as a result of the CPTPPA. Among the identified threats is the liberalization of the local market and the absence of specific regulations. Therefore, UTC need to analyze and formulate strategies in dealing with CPTPPA.

Keywords: CPTPPA, Malaysia, opportunity and challenges, share unit, SWOT, trust unit

\section{Pengenalan}

Pada tahun 2010 Malaysia telah membuat suatu keputusan strategik untuk melibatkan diri di dalam Perjanjian Perkongsian Trans-Pasifik (TPPA) yang melibatkan perjanjian perdagangan serantau merangkumi 12 buah negara iaitu iaitu Australia, Brunei, Kanada, Chile, Jepun, Malaysia, Mexico, New Zealand, Peru, Singapura, Amerika Syarikat (AS) dan Vietnam. Walaupun Amerika Syarikat telah menarik diri daripada TTPA pada 23 Januari 2017, Malaysia dan 10 negara lain telah menandatangani satu perjanjian yang dikenali sebagai Perjanjian Komprehensif dan Progresif TTPA (CPTTPA). Antara faktor utama penyertaan Malaysia dalam perjanjian CPTPPA adalah disebabkan oleh: 1) konsep ekonomi terbuka, 2) saiz pasaran domestik yang kecil dan bergantung kepada perdagangan antarabangsa, 3) kemasukan teknologi luar dan 4) sokongan industri pelancongan. Antara matlamat perjanjian kerjasama perdagangan antarabangsa ini adalah untuk memberikan ransangan kepada perkembangan pasaran di Malaysia. Pertumbuhan pasaran yang baik penting kerana ia menggalakkan pelaburan aktif dalam pasaran modal di Malaysia dan negara-negara yang terlibat dalam CPTPPA. Maka, peningkatan prestasi Indeks Komposit Kuala Lumpur (IKKL) menjadi petunjuk kepada pelabur antarabangsa untuk meningkatkan pegangan aset kewangan di Malaysia dalam portfolio pelaburan mereka di Malaysia (Zulkefly et al., 2016).

Bagaimanapun, ketersediaan pasaran Malaysia terutamanya pasaran pelaburan masih kurang difahami. kajian ini memilih SUAM kerana ia berperanan sebagai sebuah platform pelaburan yang menguruskan dana secara professional untuk membuat pelaburan dalam pasaran modal (Keng, 2000). Pulangan yang dijana oleh sesebuah SUA bergantung kepada agihan dan peruntukan portfolio yang telah ditetapkan seperti dana ekuiti dan dana pendapatan tetap (Aminah \& Zahariah, 2015). Untuk memastikan pencapaian sesebuah dana memenuhi objektif yang telah ditetapkan dan menghasilkan pulangan yang memberansangkan, SUA perlu memastikan bahawa strategi pelaburan sentiasa selari dengan keadaan ekonomi semasa sama ada di peringkat tempatan mahupun antarabangsa (Nor Azlida et al., 2010). Oleh itu, sebarang perjanjian perdagangan yang telah ditandatangani oleh setiap negara akan memberi perubahan kepada pasaran modal. Begitu juga pelaburan luar negara yang dipengaruhi oleh halangan dan risiko perdagangan antarabangsa seperti duti stem, tarif, matawang dan tukaran asing, pelaburan langsung asing, inflasi, keadaan politik, polisi kerajaan, kadar faedah dan kedudukan bon (Wan Shahidah et al., 2013). Berlandaskan teori pulangan dan risiko, kajian ini menganalisa apakah kekuatan, kelemahan, peluang dan ancaman yang dihadapi oleh SUA dalam CPTPPA. Teori pulangan dan risiko menyatakan 
bahawa pencapaian sesebuah dana adalah berdasarkan pulangan yang dapat dihasilkan yang berkaitan dengan risiko yang dihadapi melalui strategi pengurusan portfolio dan peruntukan aset oleh pengurus dana (Markowitz, 1952). Disebabkan CPTPPA memberi kesan kepada portfolio aset pelaburan bagi pasaran modal, maka SUA perlu membuat persediaan, iaitu dengan mengetahui apakah kekuatan, kelemahan, peluang dan ancaman yang bakal dihadapi oleh mereka.

\section{Sorotan literatur}

Bahagian ini membincangkan latar belakang CPTTPA, kajian empirikal berkaitan SUA, dan penerangan analisis SWOT.

\section{Latarbelakang CPTTPA}

Perjanjian CPTPPA (sebelum ini TPPA) merupakan perjanjian perdagangan bebas untuk menyelesaikan masalah kepada kerjasama ekonomi serantau. CPTTPA bertujuan menjadikan kerjasama ekonomi lebih efisien dan bersifat komprehensif. Tujuan CPTTPA adalah untuk menyelesaikan masalah pertindihan perjanjian perdagangan antarabangsa secara bilateral di antara negara-negara rantau Asia Pasifik yang memfokus kepada perjanjian secara multilateral (Elms, 2013). Hamanaka (2014) mencadangkan dua pendekatan dalam merangka TTPA, iaitu melalui: 1) pendekatan pengembangan - perjanjian dimulakan melalui kerjasama perdagangan beberapa negara dalam gabungan kecil, diikuti dengan penambahan kemasukan negara yang bersetuju memberi komitmen terhadap perjanjian yang dipersetujui bersama, dan 2) pendekatan penyelarasan - mengharmonikan perjanjian bilateral sedia ada sehingga negara-negara yang terlibat dalam perjanjian tersebut mencapai persetujuan bersama. Kajian perjanjian perdagangan bebas untuk mengantikan dan menyelaraskan perjanjian bilateral sedia ada telah dijalankan oleh Lewis (2011), Legge et al. (2011), Capling (2011), Lim and Elms (2012), Elms and Lim (2012), Elms (2013a, b), Kerr (2013), Haugen (2014), Poh (2014), Xiao (2015), Chia (2015), Wilson (2015), dan Allee \& Lugg (2016).

Petri dan Plummer (2016) menjangkakan jumlah kemasukan pelaburan ke negaranegara TPPA berkembang sebanyak USD446 billion pada tahun 2030 akibat dari peningkatan KDNK dan pengurangan halangan pelaburan. Selain itu, Jeffrrey (2016) mendapati bahawa TPPA perlu dilaksanakan kerana wujudnya trend peningkatan kecenderungan negara-negara rantau Asia Pasifik terhadap perjanjian perdagangan bebas yang lebih besar. Hamanaka (2010) menunjukkan bukti empirikal bahawa perjanjian perdagangan bebas memberikan implikasi positif kepada pertumbuhan ekonomi dengan mengurangkan ketidakstabilan firma melalui polisi perdagangan yang dapat mengurangkan konflik. Manakala, Banga (2015) menunjukkan bahawa purata tahunan eksport dan imbangan perdagangan Malaysia dijangka berkurang sebanyak masing-masing USD17 (RM66) billion dan USD1.5 (RM5.8) billion.

\section{Dana unit amanah dan teori pulangan dan risiko}

Kajian bagi SUA berkaitan teori risiko-pulangan menggunapakai model Markowit (1952), Treynor (1965), Sharpe (1966), Jensen (1968), Snail Trail, dan M-square (Norman et al., 2013; Mansor et al., 2015; Marzuki dan Worthington, 2015; Anwar Hasan 2017; Oh et al, 2017; Tan et al, 2017; Ruzita et al., 2017; Naz et al., 2017, Ameer Ali, 2017; Shahrin, 2018; dan Abdul-Rahim et al., 2019). Hasil kajian mendapati bahawa pulangan dana unit amahah (DUA) mempunyai hubungan dengan kecekapan pengurus dalam membuat keputusan 
portfolio pelaburan berdasarkan tahap penerimaan risiko yang berbeza-beza (sama ada dana bersifat agresif atau pasif).

Seterusnya, kajian DUA melihat kepada kecekapan pengurus dana yang mempengaruhi pencapaian DUA melalui kemahiran Pemasaan Pasaran, Pemilihan Sekuriti dan Prestasi dana (Teoh, 2012; Kumar, 2012; Soo-Wah, 2013; Choong et al., 2012; Alam, 2013; Ali et al., 2015, Hafinaz dan Nazimah, 2018; dan Norazlina dan Nurul, 2018). Secara umumnya, dapatan kajian menunjukkan risiko dana berhubungan negatif dengan pemilihan sekuriti, tetapi berhubungan positif dengan pemasaan pasaran. Ini menunjukkan bahawa pengurus yang menumpukan kepada aktiviti pengkhususan pemilihan saham berkemungkinan menunjukkan prestasi yang lemah apabila berhadapan dengan risiko tinggi akibat daripada pergerakan pasaran yang luas. Oleh itu, dana yang bersaiz besar lebih baik diuruskan oleh pengurus yang mempunyai kemahiran pemasaan pasaran (Soo Wah, 2013).

Selain itu, wujud pengaruh makroekonomi ke atas pulangan nilai aset bersih DUA (Wan Shahidah et al., 2013). Data makroekonomi seperti Indeks Harga Pengguna (IHP) dan Keluaran Dalam Negara Kasar (KDNK) juga berhubungan positif dengan pulangan DUA. Apabila IHP meningkat, ramai pelabur membuat pelaburan ke dalam DUA berbanding instrumen pelaburan lain kerana pendedahan risiko DUA lebih rendah. Manakala Kadar Pinjaman Asas (KPA) dan Indeks Komposit Kuala Lumpur (IKKL) berhubungan negatif dengan DUA kerana kenaikan KPA menyebabkan ramai menukar portfolio pelaburan dari ekuiti kepada bon atau instrument pasaran wang yang lebih rendah risikonya. Kajian gelagat pelabur pula menunjukkan ciri-ciri pelabur di Malaysia majoritinya berusia linkungan 26-45 tahun, graduan siswazah dan pascasiswazah serta memahami teknologi kewangan yang berpotensi membuat pelaburan merentasi sempadan (Abdullah et al., 2018).

\section{Analisis SWOT}

Analisis SWOT (Dosher et al, 1960) yang merangkumi kekuatan, kelemahan, peluang dan ancaman bertujuan memberikan gambaran jelas mengenai kekuatan syarikat yang boleh dipertingkatkan lagi bagi memenuhi objektif perniagaan. Selain itu, ia juga boleh mengenal pasti kelemahan syarikat agar sesuatu strategi yang diambil mengambilkira kelemahan ini. Analisis ini juga membantu syarikat mempamerkan kemungkinan peluang dan ancaman yang ada di hadapan. Namun begitu, terdapat kelemahan dalam analisis SWOT memandangkan ia hanya merangkumi isu-isu yang pasti dapat dianggap sebagai kekuatan, kelemahan, peluang atau ancaman. Maka, sukar untuk menangani faktor yang tidak pasti. Analisis SWOT digunakan dalam kajian ini bukan bertujuan untuk melihat dan menangani isu yang tidak pasti, namun ia bertujuan untuk memahami keadaan sebenar yang dialami oleh SUA dalam CPPPA.

\section{Metodologi Kajian}

Kaedah kualitatif dipilih untuk memahami fenomena berkaitan kesan CPTTPA ke atas kajian kes dengan mengambilkira garispanduan kaedah interpretatif dalam sistem yang terikat (Merriam \& Tisdell 2016). Kaedah yang dipilih bersesuaian dengan tujuan penyelidikan kualitatif iaitu untuk menghasilkan pemahaman dan pengetahuan mendalam mengenai fenomena tertentu (Leininger, 1994) melalui penerokaan secara terperinci dan deskriptif (Chua 2012; Othman 2015). Selain kaya dengan data, kekuatan kajian kualitatif adalah ia dikenali sebagai strategi terbaik untuk penemuan dan menjelajahi bidang baharu (Miles \& Huberman, 1994). 
Sebanyak enam soalan temubual telah digubal berdasarkan model SWOT dan kajian lepas seperti kajian Institut Strategik dan Kajian Antarabangsa (The Star, 2015), firma audit PricewaterhouseCoopers (PwC, 2015), Peterson Institute for International Economics (Jomo, 2016) dan Kementerian Perdagangan Antarabangsa dan Industri (MITI, 2015). Teknik temubual separa-berstruktur dengan pengurus SUA dilaksanakan dengan mengajukan soalansoalan berikut:

1. Apakah kesan CPTTPA terhadap syarikat unit amanah? Bagaimanakah persediaan syarikat menghadapinya?

2. Apakah kekuatan dan kelemahan sedia ada bagi syarikat anda dalam menghadapi CPTTPA?

3. Apakah peluang dan cabaran ke atas pasaran modal kesan dari CPTTPA?

4. Bagaimanakah syarikat menghadapai cabaran turun-naik nilai matawang akibat CPTTPA?

5. Bagaimanakah kesan perubahan pasaran akibat daripada perubahan permintaan barangan pengguna apabila halangan cukai dan tarif dihapuskan dalam CPTPPA?

6. Bagaimanakah perubahan strategi pengurusan portfolio terhadap dana-dana yang terlibat dalam pelbagai sektor yang berkaitan CPTPPA?

Peserta kajian dipilih berdasarkan berpengalaman mereka dalam menguruskan pelaburan dana di dalam negara atau luar negara, pengetahuan mereka tentang topik-topik berkaitan dengan perjanjian CPTPPA, struktur ekonomi, KDNK dan faktor-faktor makroekonomi yang mempengaruhi pasaran modal dan strategi portfolio pelaburan DUA. Selain itu, SUA yang terlibat adalah syarikat yang membuat pelaburan ke negara-negara yang menandatangi perjanjian CPTPPA. Jadual 1 memperincikan peserta, jawatan dan SUA. Perbualan dirakamkan dengan menggunakan pita rakaman dengan persetujuan responden.

Jadual 1. Profil responden

\begin{tabular}{ccc}
\hline Responden & Jawatan & Syarikat \\
\hline Ahmad & Pengurus Pelaburan Dana & Syarikat X \\
Borhan & Pengurus Pelaburan Dana & Syarikat Y \\
Chairil & Pengurus Pelaburan Dana & Syarikat X \\
Dahalan & Pengurus Pelaburan Dana & Syarikat Z \\
\hline
\end{tabular}

Proses pengumpulan dan analisis data dijalankan secara serentak. Rakaman temubual ditranskripsi terlebih dahulu untuk tujuan analisa. Kajian ini menggunakan kaedah sistematik dalam menganalisa data iaitu secara deskripsi terperinci dengan melihat perubahan yang kerap berlaku sama ada pada peringkat kata, ayat atau frasa (Meriam, 2002). Selain itu, analisis data juga dilakukan berpandukan rangkakerja SWOT (Dosher et al., 1960) tentang Kekuatan, Kelemahan, Peluang dan Ancaman. Pengumpulan data berhenti apabila tiada lagi data baru yang dihasilkan (Faulkner \& Trotter, 2017).

\section{Dapatan dan perbincangan}

Perbincangan mengenai analisa SWOT adalah seperti berikut: 


\section{Kekuatan}

Kajian ini mendapati kemahiran strategik pelaburan dan kepelbagaian instrumen pelaburan baru adalah dua dimensi kekuatan yang dimiliki oleh syarikat unit amanah dalam membuat persediaan untuk menepani cabaran CPTPPA.

a. Kemahiran strategik pelaburan

Berdasarkan dapatan kajian, strategi pelaburan yang akan dilaksanakan adalah berdasarkan analisa yang mendalam dan menyeluruh ke atas keadaan ekonomi semasa, pencapaian industri dan analisis pencapaian syarikat yang tersenarai di pasaran saham. Analisis tersebut dibuat melalui dua kaedah iaitu kaedah kuantitatif dan kualitatif seperti kenyataan berikut.

\section{Kaedah kuantitatif}

Kami tengok pencapaian syarikat dengan membuat analisis melalui pembacaan. Kami pakai excel untuk analisa carta teknikal dan guna model simulasi dengan memasukkan maklumat syarikat... Kemudian, sistem akan keluarkan keputusan.

(Ahmad)

Selalunya kita akan pakai pendekatan dari atas ke bawah, kita tengok semua faktor ekonomi mengikut sektor. Contohnya, sektor Elektronik, kalau patuh shariah, kita perincikan lagi. Kemudian guna beberapa nisbah kewangan seperti ROI dan ROE.

(Borhan)

Kami menggunakan sistem portfolio, yang merangkumi sistem sokongan belakang dan hadapan bagi menganalisa data dari Bloomberg dan Reuters.

(Chairil)

Kami lihat dan analisa maklumat semasa belanjawan negara seperti dasar fiskal kewangan negara macam insentif cukai, peruntukan perbelanjaan projek pembangunan.

(Dahalan)

\section{$\underline{\text { Kaedah kualitatif }}$}

... kami dapatkan maklumat daripada broker, Bloomberg, buat lawatan ke syarikat dan dapatkan maklumat daripada pemain industri. Kami juga pantau pihak pengurusan dan lembaga pengarah sebelum melabur....

(Borhan)

...kami akan pergi buat lawatan ke syarikat dan tengok proses 'book order' dalam pecarian petunjuk untuk perancangan suku tahun, dan seterusnya.

Kekuatan yang dimiliki oleh pengurus dalam menganalisa pasaran semasa bergantung kepada kemahiran mereka seperti pemasaan pasaran dan pemilihan saham. Bagi mengoptimumkan perolehan pelaburan, pengurus perlu mengumpul maklumat kuantitatif dan kualitatif. Maklumat kuantitatif merangkumi proses penilaian dasar ekonomi kerajaan dan kajian masa depan ekonomi negara seperti kitaran ekonomi (economic cycle), kitaran 
perniagaan, dasar fiskal, perkembangan ekonomi dunia dan serantau, perdagangan antarabangsa, kadar pertumbuhan ekonomi (KDNK), kadar inflasi, kadar pengangguran dan tahap produktiviti negara. Dapatan ini selari dengan kajian yang dijalankan oleh Mohamed Hisham et al. (2013). Kajian ke atas masa depan industri juga dilaksanakan seperti menganalisa peluang pasaran, persaingan, permintaan dan dan penawaran untuk mendapatkan jangkaan perkembangan industri masa hadapan. Manakala, analisis bagi syarikat memfokuskan kepada pertumbuhan perolehan, dividen, risiko pelaburan, penyata untung-rugi, aliran tunai, kunci kira-kira, serta struktur pentadbiran. Maklumat kualitatif merujuk kepada maklumat yang diperolehi daripada pihak luar seperti Bloomberg, broker dan lawatan ke syarikat. Di samping itu, maklumat berkaitan pengurusan dalaman syarikat seperti perlantikan pengurus besar, ahli lembaga pengarah dan perlantikan juruaudit luar perlu diambil kira (Mohamed Hisham et al., 2013). Kedua-dua maklumat kuantitatif dan kualitatif membantu pengurus dana untuk membuat analisis perbandingan antara syarikat yang bakal dilabur dan syarikat yang menjadi peneraju dalam industri itu

Berdasarkan dapatan kajian di atas adalah dijangkakan pengurus dana yang mempunyai kemahiran strategik pelaburan yang cekap dan sentiasa membuat analisa ke atas keadaan pergerakan pasaran semasa akan berjaya dalam membuat keputusan terhadap pemilihan saham dan pemasaan pasaran. Contohnya, apabila CPTPPA dilaksanakan, pengurus dana yang mempunyai kemahiran ini akan berupaya membuat ramalan pergerakan saiz pasaran yang luas (Soo Wah, 2012). Ini sejajar dengan Teori Pemasaan Pasaran bahawa pengurus dana yang mempunyai maklumat yang pantas, terkini dan tepat akan dapat membuat analisis ke atas pergerakan pasaran (Treynor \& Mazuy 1966). Mereka juga mampu untuk menguruskan risiko pelaburan dan dapat menguruskan pencapaian dana yang baik selari dengan Teori Nisbah Maklumat (Treynor \& Black, 1973).

\section{b. Kepelbagaian instrumen pelaburan}

Kekuatan pengurus dinilai melalui keupayaan mempelbagaikan instrumen pelaburan untuk menarik kemasukan pelaburan baru dari negara-negara CPTPPA.

...Di Malaysia, penerbitan sukuk sangat diharapkan kerana pasaran masih kurang. Diharapkan CPTPPA memberi peluang kepada syarikat-syarikat untuk meneroka perniagaan baru.

(Ahmad)

...ada syarikat kewangan yang menawarkan sukuk ke luar negara. Jadi, dengan adanya CPTTPA nanti, syarikat Unit Amanah boleh mengambil peluang dengan menawarkan produk baru yang melabur dalam sukuk...

(Borhan)

Pengurus yang cekap mampu mengeluarkan instrumen pelaburan baru melalui danadana bersifat merentasi sempadan bagi memenuhi permintaan pelabur luar negara.

Merentasi sempadan, maknanya pelabur dari luar negara boleh membeli produk tempatan, kerana semua pelabur terlibat dengan transaksi atas talian yang terbuka secara global. Sekarang, pelabur luar negara boleh beli produk Unit Amanah tempatan dan kita juga boleh beli produk luar negara. 
Setiap negara mempunyai organisasi seperti SC yang membuat perjanjian untuk membenarkan pelaburan antara negara-negara...

(Chairil)

Melalui CPTPPA, SUA yang mempunyai kekuatan pencapaian dana yang baik dapat memperluaskan pasaran dengan menawarkan dana tersebut kepada pelabur luar negara sama ada bagi pasaran negara maju seperti Jepun, Australia, New Zealand dan Singapura mahupun pasaran negara membangun seperti Vietnam, Chile, Mexico, Peru dan Brunei.

\section{Kelemahan}

Terdapat dua kelemahan SUA iaitu ketiadaan persediaaan ke atas CPTPPA dan ketiadaan persediaan mengeluarkan dana di peringkat antarabangsa.

a. Ketiadaan persediaan ke atas perjanjian CPTPPA

Ketiadaan persediaan oleh SUA terhadap kesan CPTPPA disebabkan tiada perbincangan formal oleh pihak pengawal selia.

Setakat ini tiada persediaan syarikat Unit Amanah ke atas CPTPPA.

(Borhan)

Masih tiada lagi perancangan untuk menghadapi CPTPPA.

(Chairil)

Persediaan secara spesifik memang tiada, sebab kita tiada maklumat lengkap.

(Dahalan)

Kesan ketiadaan maklumat tepat menyebabkan tiada persediaan merangka strategi pengurusan portfolio seperti strategi pemilihan saham dan pemasaan pasaran secara spesifik. Hasil kajian menunjukkan bahawa persediaan perlu dilakukan oleh SUA apabila berlakunya pergerakan dan perluasan pasaran akibat CPTPPA.

b. Ketidakupayaan pengeluaran dana di peringkat antarabangsa

Apabila berlaku pelaburan merentasi sempadan yang lebih luas dan agresif, syarikat Unit Amanah di Malaysia akan berdepan dengan aliran modal yang tinggi (Allen et al, 2020). Justeru, SUA perlulah mempunyai keupayaan menawarkan produk yang menghasilkan pulangan yang tinggi. Oleh itu, SUA perlu memastikan bahawa pengurus dana mempunyai kemahiran yang baik bagi mempertingkatkan pencapaian DUA kepada tahap yang tertinggi (Ruzita et al., 2017).

...Untuk keluarkan produk yang lebih canggih kami belum bersedia kerana persediaan memerlukan maklumat dan sokongan dari pihak tertentu. 
Kami syarikat kecil tidak fokus kepada luar negara, tetapi hanya tertumpu kepada pasaran tempatan kerana kurang kemampuan tawarkan produk yang kompetitif. Pasaran tempatan lebih selamat sebab kami dah biasa dengan pasaran tempatan.

(Dahalan)

Peluang

Terdapat empat peluang utama yang diperolehi oleh SUA apabila CPTPPA dilaksanakan.

a. Mempelbagaikan portfolio pelaburan di peringkat antarabangsa

Kemasukan pelaburan antarabangsa yang lebih banyak akan membuka peluang luas kepada pengurus DUA untuk mengeluarkan produk yang bersesuaian dengan perubahan pasaran semasa.

Lepas CPTPPA, syarikat boleh pergi ke pasaran yang lebih luas, sekaligus boleh mencipta lebih banyak produk. Sekarang ini, kebanyakan pelaburan asing di Malaysia tertumpu kepada pelaburan ekuiti dan hartanah, kurang pada Unit Amanah.

(Ahmad)

Kesan CPTPPA lebih kepada industri perkilangan, pembuatan dan syarikat-syarikat multinasional. Kami akan tingkatkan pelaburan dalam syarikat-syarikat yang mempunyai kesan positif daripada CPTPPA dan kurangkan pelaburan dalam syarikat-syarikat yang mendapat kesan buruk.

(Borhan)

... Lebih banyak negara, lagi banyak saham yang boleh dipilih. Dengan CPTPPA sudah tentu peredaran modal pelaburan lagi memberansangkan. Maknanya lagi tinggi kemungkinan kita boleh kaut keuntungan dari saham negara luar seperti Korea, US dan Jepun. Kualiti saham mereka tinggi macam Honda dan Samsung. Kalau kita ada akses dengan tiada sekatan memang ia sangat bagus untuk pasaran saham.

(Chairil)

Pelabur akan ada peluang yang besar untuk melabur dalam pasaran saham, pengurus dana luar akan membuat pelaburan dekat negera kita, pemegang Unit Amanah dari negara lain juga akan membuat pelaburan dekat sini.

(Dahalan)

b. Peningkatan KDNK dan komposisi eksport negara

Peningkatan KDNK negara menjadi penanda aras bagi para peserta pasaran dari luar negara untuk melabur dalam syarikat multinasional (Bindu, 2020). Syarikat multinasional Malaysia dijangka menikmati peluang untuk meneroka ekonomi perindustrian negara lain yang berkembang pesat serta mengambil manfaat eksport baru dengan meningkatkan kelebihan daya saing yang disediakan oleh CPTPPA. 
Saya rasa kemungkinan itu ada memberi kesan kepada syarikat-syarikat yang terlibat secara langsung mempunyai perniagaan import eksport, juga memberi kesan secara langsung kepada KDNK.

(Ahmad)

Sudah tentu KDNK akan meningkat, sesetengah sektor akan dapat manfaat. Tetapi sesetengah sektor juga akan mendapat kesan negative.

(Borhan)

CPTPPA bagus untuk syarikat-syarikat yang berasaskan eksport. Contoh syarikatsyarikat yang buat tekstil seperti Magnitec akan eksport kepada negara yang terlibat dengan CPTPPA. Kita jangkakan saham syarikat macam ni akan meningkat.

(Dahalan)

Walaupun CPTPPA tidak mempunyai kesan langsung ke atas pasaran modal kerana lebih tertumpu kepada industri-industri seperti eletronik, tekstil, petrokimia, makanan, kayukayan dan getah (Izurieta et al, 2018), namun syarikat-syarikat yang tersenarai di Bursa Malaysia yang terlibat di dalam perdagangan antarabangasa akan terkesan ke atas pencapaian industri tersebut. Oleh itu, SUA perlu bersedia dari segi kepakaran membuat analisa ke atas pasaran saham Malaysia apabila kemasukan modal daripada negara-negara CPTPPA meningkat.

c. Instrumen pelaburan baru merentasi sempadan

SUA mempunyai peluang untuk menawarkan produk yang lebih bersifat global (Jamaludin et al., 2014) yang dapat menarik pelabur asing.

... disebabkan pengecualian cukai bagi pelaburan merentas sempadan, pengurus unit amanah dapat membuka peluang kepada syarikat gergasi dalam kalangan CPTTPA untuk melabur dalam produk baru yang akan kita tawarkan sesuai dengan kehendak mereka.

(Borhan)

Syarikat kami mungkin mempunyai kelebihan untuk menawarkan produk unit amanah di sana luar negara terutamanya produk Islamik.

(Chairil)

Contohnya syarikat RHB investment ada satu dana seperti RHB Global fund, yang mengumpulkan modal daripada Arab, China, Eropah. Begitu juga dengan Kuwait Finance House, mereka ada satu dana khas yang modalnya datang dari GCC. Dengan adanya CPTTPA, kalau pencapaian ekonomi dan pasaran saham kita baik, syarikat berpeluang mengeluarkan produk baru.

(Dahalan)

d. Sokongan pihak kerajaan

Pelan Utama Pasaran Modal 1 dan 2 merupakan sokongan pihak kerajaan untuk menjadikan pasaran modal di Malaysia menjadi lebih aktif (Woodsome, 2016). Pelan ini membantu SUA 
menghadapi cabaran pergerakan pasaran akibat daripada liberalisasi perdagangan antarabangsa.

Kesan langsung dari CPTPPA, kita tidak nampak lagi, tapi setahu saya kerajaan sentiasa mengawal selia dan menambah baik pasaran modal. Contohnya, Pelan Utama Pasaran Modal.

(Borhan)

Suruhanjaya Sekuriti telah buat 'blue print' bagaimana kita nak membuat pelaburan keluar negara dan macam mana nak menarik pelabur ke Malaysia. Ini selari dengan matlamat CPTPPA.

(Chairil)

\section{Ancaman}

Terdapat tiga ancaman utama yang dihadapi oleh SUA apabila CPTPPA dilaksanakan.

a. Pergerakan pasaran antarabangsa

Pergerakan pasaran antarabangsa adalah aliran keluar masuk perdagangan dan pelaburan antara satu negara dengan negara yang lain. Pergerakan ini akan menyebabkan berlakunya turun-naik pasaran pertukaran matawang (Choi, 2020). Ini mengakibatkan pasaran unit amanah menjadi lebih agresif. Oleh itu, pengurus perlu peka dan proaktif terhadap perkembangan pasaran untuk pemasaan pasaran dan pemilihan saham.

... CPTPPA mungkin menyebabkan ekonomi lebih terbuka, jadi pasaran saham akan turun-naik, dan ini akan memberi kesan kepada syarikat yang terlibat dalam perniagaan eksport import.

(Borhan)

Selain itu, dalam menghadapi pergerakan pasaran antarabangsa ini, SUA perlu mengambilkira keadaan ekonomi, perbezaan budaya, polisi dan kepercayaan yang diamalkan oleh negara-negara CPTTPA sebelum melakukan pelaburan.

...negara kecil macam kita dan Thailand, walaupun kita negara Asia, kita perlukan masa untuk biasakan dengan keadaan ekonomi masing-masing. Sebab budaya dan kepercayaan kita berbeza, cara melakukan perniagaan, dan penguatkuasaan dari bank pusat juga berbeza.

(Chairil)

Kalau macam pengurus dana yang besar EPF, PNB dia ada pendapatan yang besar, dia boleh keluarkan dana baru dan dia boleh meneroka pasaran baru. Saya rasa syarikat bersaiz sederhana akan lebih terkesan dengan CPTPPA. Tidak mudah kalau kami nak beralih pelaburan kepada negara-negara CPTPPA kerana berbezaan polisi dan budaya, kecuali ada 'competive advantage'. 
Dapatan kajian ini selari dengan hasil kajian oleh Anwar Hasan (2015) yang mendapati bahawa terdapat hubungan antara harga DUA Islam dengan pembolehubah makroekonomi seperti krisis kewangan dan kadar pertukaran asing. Oleh itu, pengurus perlu sentiasa peka terhadap turun-naik matawang asing, cerdas dalam memahami perbezaan budaya, polisi dan amalan perniagaan negara yang ingin dibuat pelaburan.

b. Penghapusan tarif dan permintaan barangan pengguna

CPTPPA menghapuskan tarif dan bukan tarif yang akan memberi kesan kepada Indeks Harga Pengguna (IHP), iaitu perubahan ke atas komposisi permintaan barangan pengguna (Raynolds, 2020). Apabila IHP menurun, ia akan mengurangkan kadar inflasi yang menyebabkan kuasa beli pengguna meningkat. Pengguna mungkin cenderung membuat pelaburan di pasaran saham yang memberikan pulangan yang tinggi berbanding DUA.

... CPTPPA menyebabkan kos perniagaan berkurang akibat penghapusan tarif...mungkin CPTPPA akan kurangkan daripada 30 peratus kepada 5 peratus. Jadi firma boleh tawarkan barang pada harga yang lebih murah, menyebabkan permintaan terhadap saham firma meningkat, lalu mengurangkan permintaan DUA.

(Borhan)

...kalau inflasi rendah, kuasa beli pengguna tinggi. Bila pelabur ada duit lebih, biasanya mereka akan pilih untuk beli saham walaupun risiko tinggi sebab nak pulangan yang tinggi.

(Dahalan)

c. Liberalisasi pasaran tempatan

Liberalisasi perdagangan yang lebih luas memberikan ancaman kepada pasaran saham tempatan (Chen, 2020). CPTPPA akan menjadikan persaingan di antara syarikat-syarikat tempatan dan luar negara lebih kompetitif. Mungkin terdapat syarikat yang tersenarai di Bursa Malaysia terkeluar kerana mengalami kerugian. Justeru, SUA lebih peka, fleksibel, aktif, dan agresif bagi memastikan portfolio pelaburan mereka sentiasa memberi pulangan yang tinggi.

...Walaupun CPTPPA ni boleh menyebabkan harga barang murah, syarikat tempatan yang kecil tak mampu bertahan sebab persaingan dari negara luar macam China... harga barang mereka lebih murah. Jadi banyak syarikat akan tutup dan terkeluar dari senarai bursa Malaysia.

(Ahmad)

...bila mana CPTPPA telah dilaksanakan, ekonomi akan menjadi lebih terbuka dan akan ada lebih banyak liberalisasi sektor industri. Jadi SUA perlu peka dengan keadaan ekonomi tanpa sempadan dengan ketidaktentuan yang tinggi. SUA perlu lebih fleksibel dan bersedia dari segi pemasaan pasaran dan pemilihan saham.

(Borhan) 
kesan CPTPPA akan meluaskan sempadan ekonomi. Untuk bersaing dengan syarikat gergasi, SUA perlu mempunyai pengurus yang bukan sahaja mahir, bahkan ada pengalaman meramal pasaran. Pengurus perlu bersedia dari segi pengetahuan tentang produk, pelaburan, dan strategi pemilihan sektor.

(Chairil)

Liberalisasi oleh CPTPPA mungkin akan mengancam syarikat tempatan dari segi keluar masuk pasaran saham. Pengurus DUA perlulah bersedia menghadapi ancaman akibat perjanjian ini. Beberapa halangan asas yang perlu ditangani seperti perbezaan suasana perniagaan dan pasaran di antara negara-negara luar iaitu seperti budaya, polisi, undangundang dan prosedur pelaburan.

\section{Kesimpulan}

Kajian ini bertujuan memahami apakah kekuatan, kelemahan, peluang dan ancaman yang bakal dihadapi oleh SUA terhadap CPTPPA. Sasaran kajian adalah untuk memberikan suatu persediaan awal kepada SUA berkaitan strategi pengurusan pelaburan DUA yang bersesuaian. Dapatan kajian menjelaskan bahawa CPTPPA tidak memberikan kesan langsung ke atas industri Unit Amanah, tetapi sedikit-sebanyak memberikan kesan tidak langsung. Pencapaian KDNK, perubahan komposisi eksport dan import, perubahan pencapaian sektorsektor ekonomi dan penghapusan halangan perdagangan (i.e tarif dan bukan tarif) memberi kesan tidak langsung ke atas prestasi syarikat-syarikat yang tersenarai di Bursa Malaysia, lalu akhirnya mempengaruhi pencapaian DUA. Ini disebabkan komposisi portfolio aset pelaburan DUA terdiri daripada kombinasi pelaburan dalam saham-saham syarikat yang tersenarai di pasaran saham. Dapatan kajian menunjukkan tiada persediaan yang dilakukan oleh SUA terhadap perlaksanaan CPTPPA. Pengurus dana seharusnya meneliti serta memahami intipati CPTTPA sebagai persediaan merangka strategi pemilihan saham dan pemasaan pasaran bagi meminimumkan risiko kerugian pelaburan serta memaksimakan keuntungan pelaburan. Ini akan mempengaruhi pencapaian DUA unutuk jangka pendek dan panjang. Pencapaian DUA yang baik akan memberi pulangan tinggi kepada pelabur individu dan pelabur institusi yang akhirnya akan meningkatkan ekonomi dan taraf hidup rakyat Malaysia.

\section{Penghargaan}

Setulus penghargaan kepada pihak Yayasan Tun Ismail Ali, Universiti Kebangsaan Malaysia (YTI-UKM: EP-2017-002)

\section{Rujukan}

Abdullah, E. M. E., Abdul-Rahman, A. \& Abdul-Rahim, R. (2018). Adoption of financial technology (Fintech) in mutual fund/unit trust investment among Malaysians: Unified Theory of Acceptance and Use of Technology (UTAUT). International Journal of Engineering and Technology (UAE), 7(2), 110-118.

Abdul Muein Abadi. (2017). Perbandingan dasar luar Malaysia dan Indonesia terhadap Amerika Syarikat dan China dari Perspektif realisme Neo-Klasik (Comparing Malaysia and Indonesia's foreign policy toward the US and China from Neoclassical Realism Perspective). Geografia-Malaysian Journal of Society and Space, 13(1), 119-132. 
Abdul-Rahim, R., Abdul-Rahman, A., \& Ling, P.S. (2019). Performance of shariah versus conventional funds: Lessons from emerging markets. Journal of Nusantara Studies (JONUS), 4(2), 193-218.

Alam, N. (2013). A comparative performance analysis of conventional and Islamic exchangetraded funds. Journal of Asset Management, 14(1), 27-36.

Allee, T., \& Lugg, A. (2016). Who wrote the rules for the Trans-Pacific Partnership? Research \& Politics, 3(3), 2053168016658919.

Allen, L., Chakraborty, S., Hazarika, S., \& Su, C.H. (2020). Bank dependence in emerging countries: Cross-border information percolation in mutual fund equity investing. Journal of International Business Studies, 51(2), 218-243.

Ali, S.H.S., \& Kamarudin, N.S. (2015). Determining ways of developing trust towards investment in unit trusts fund. J. Appl. Environ. Biol. Sci, 4(10S), 88-93.

Ameer Ali Vali Mohamed. (2017). Choosing the right investment products. Journal of Wealth Management \& Financial Planning, 4, 66-72.

Aminah Shari \& Zahariah Sahudin. (2015). The performance of unit trust industry in Malaysia. Information Management and Business Review, 7(4), 46-54.

Anwar Hasan Abdullah Othman, Ahamed Kameel, \& Hasanuddeen Abdul Azizi. (2015). Causal relationship between macro-economic indicators and funds unit prices behavior: Evidence from Malaysian Islamic equity unit trust funds industry. World Academy of Science, Engineering and Technology. International Journal of Social, Behavioral, Educational, Economic, Business and Industrial Engineering, 9(1), 192-200.

Banga, R. (2015). Trans-Pacific Partnership Agreement (TPPA): Implications for Malaysia's domestic value-added trade. Unit of Economic Cooperation and Intergration amongst Developing Countries (ECIDC) UNCTAD.

Bindu, P.K. (2020). Role of extraversion personality on mutual investment decision. Studies in Indian Place Names, 40(3), 1917-1926.

Capling, A. (2011). Investing in protection: The politics of preferential trade agreements between North and South. Pacific Affairs, 84(2), E26.

Chen, S., Ni, S.X., \& Tong, J. (2020). Impact of recent Chinese stock market liberalization: History and literature review. Available at SSRN 3539276.

Chia, S.Y. (2015). Emerging Mega-FTAs: Rationale, challenges, and implication. Asian Economic Papers, 14(1), 1-27.

Choi, J.H. (2020). Capital controls and foreign exchange market intervention. Journal of International Money and Finance, 101, 102098.

Choong, Y.V., Thim, C.K., Fie, D.Y.G., \& Ng, C.H. (2012). Development and performance trends of Malaysian unit trusts. Journal of Modern Accounting and Auditing, 8(12), 1804.

Dosher, M., Benepe, O., Humphrey, A., Stewart, R., \& Lie, B. (1960). The SWOT analysis method. Mento Park, CA: Stanford Research Institute.

Elms, D.K. (2013a). The Trans-Pacific Partnership Agreement: Looking ahead to the next steps. ADBI Working Paper Series 447.

Elms, D. K. (2013b). The Trans-Pacific partnership trade negotiations: some outstanding issues for the final stretch. Asian J. WTO \& Int'l Health L \& Pol'y, 8, 379.

Elms, D.L \& Lim, C.L. (2012). The Trans-Pacific Partnership Agreement (TPP) negotiations: Overview and prospects. RSIS Working Paper 232.

Faulkner, S.L. \& Trotter, S.P. (2017). Data saturation. The International Encyclopedia of Communication Research Methods. 1-2. Retrieved from https://onlinelibrary.wiley.com/ doi/abs/10.1002/9781118901731.iecrm0060.

Jomo, K.S. (2016). Lessons from the Dead: The Trans-Pacific Partnership Agreement as Model Free Trade Agreement. Development, 59(1-2), 48-52. 
Hafinaz Hasniyanti Hassan, \& Nazimah Hussin. (2018). Conceptual framework for the determinants of mutual fund performance in Malaysia. Journal of Finance and Banking Review, 3(4), 48-53.

Hamanaka, S. (2014). TPP versus RCEP: Control of membership and agenda setting. Journal of East Asian Economic Integration, 18(2), 163-186.

Haugen, H.M. (2014). How are indigenous and local communities' rights over their traditional knowledge and genetic resources protected in current free trade negotiations? Highlighting the draft trans-pacific partnership agreement (TTPA). The Journal of World Intellectual Property, 17(3-4), 81-95.

Izurieta, A., Kohler, P., \& Pizarro, J. (2018). Financialization, trade, and investment agreements: Through the looking glass or through the realities of income distribution and government policy? UNCTAD \& Global Development and Environment Institute Working Paper No. 03, 18.

Jamaludin, N., Smith, M., \& Gerrans, P. (2012). Mutual fund selection criteria: evidence from Malaysia. Asian Review of Accounting, 20(2): 140-151

Jeffrey H. Bergstrand. (2016). Should TPP be formed? On the potential economic, governance, and conflict-reducing impacts of the Trans-Pacific Partnership Agreement. East Asian Economic Review, September 20(3), 279-309.

Jensen, M.C. (1968). The performance of mutual funds in the period 1945-1964. The Journal of Finance, 23(2), 389-416.

Keng, T.Y. (2000). Unit trust performance measurement: the snail trail approach. Pertanika J. Soc. Sci. \& Hum, 8(2), 103-114.

Kerr, W.A. (2013). Negotiating in disequilibrium: can a Trans-Pacific Partnership be achieved as potential partners proliferate? Estey Journal of International Law and Trade Policy, 14(1753-2016-141248), 39-50.

Kumar, V. (2012). Performance evaluation of open ended schemes of mutual funds. Sumedha Journal of Management, 1(1), 27-42.

Legge, D., Gleeson, D., Snowdon, W., \& Thow, A.M. (2011). Trade agreements and noncommunicable diseases in the Pacific islands. In Pacific NCD Forum (Vol. 2011).

Lewis, M.K. (2011). The Trans-Pacific Partnership: New Paradigm of Wolf in Sheep's Clothing. BC Int'l \& Comp. L. Rev., 34, 27.

Lim, C.L., Elms, D.K., \& Low, P. (Eds.). (2012). The trans-pacific partnership: A quest for a twenty-first century trade agreement. Cambridge University Press.

Low Soo-Wah. (2013). Investment performance analysis of managerial expertise: Evidence from Malaysia-based international equity unit trust funds. Jurnal Pengurusan, 38, 4151.

Mansor, F., Bhatti, M.I., \& Ariff, M. (2015). New evidence on the impact of fees on mutual fund performance of two types of funds. Journal of International Financial Markets, Institutions and Money, 35, 102-115.

Markowitz, H. (1952). Portfolio selection. The Journal of Finance, 7(1), 77-91.

Marzuki, A., \& Worthington, A. (2015). Comparative performance-related fund flows for Malaysian Islamic and conventional equity funds. International Journal of Islamic and Middle Eastern Finance and Management, 1(4), 285-303

Merriam, S.B. \& Tisdell, E. (2016). Qualitative Research: A Guide to Design and Implementation. 5th edition. San Francisco: Jossey-Bass Publishers

MITI report (2016). The Ministry of International Trade and Industry. Retrieve from https://www.miti.gov.my/miti/resources/MITI\%20Report/MITI_REPORT_2016.pdf

Naz, I., Shah, S.M.A., \& Kutan, A.M. (2017). Do managers of sharia-compliant firms have distinctive financial styles? Journal of International Financial Markets, Institutions and Money, 46, 174-187. 
Nor Azlida Aleng @ Mohamad, Wan Muhamad Amir Wan Ahmad, \& Mustafa Mamat. (2010). Analisis kecekapan relatif bagi industri saham amanah menggunakan pendekatan ekonometrik. International Journal of Management Studies (IJMS), 17(1), 189-202.

Norazlina Ripain \& Nurul Wajhi Ahmad. (2018). An overview of unit trust funds in Malaysia. Reports on Economics and Finance, 4(3), 117-123.

Norman, N., Almsafir, M.K., \& Smadi, A. (2013). Comparative study of conventional and Shariah based unit trust funds performance of Public Mutual Berhad. Australian Journal of Basic and Applied Sciences, 7(9), 354-363.

Oh, N.Y., Parwada, J.T., \& Tan, E.K. (2017). Should indirect brokerage fees be capped? Lessons from mutual fund marketing and distribution expenses. Journal of Financial and Quantitative Analysis, 52(2), 781-809.

Othman Lebar. (2015). Penyelidikan kualitatif: Pengenalan kepada teori dan metod. Penerbit Universiti Pendidikan Sultan Idris.

Petri, P.A \& Plummer, M.G. (2016). The economic effects the Trans-Pacific Partnership: New estimates. Working Paper Series, Peterson Institute for International Economics.

Poh, L.P. (2014). Malaysia's interest in the Trans Pacific Partnership Agreement (TPPA). Thesis Faculty of Social Sciences and Humanities. Universiti Kebangsaan Malaysia.

PwC. (2015). Study on potential economic impact of TPPA on the Malaysian economy and selected key economic sectors. Pricewaterhousecoopers (PwC).

Reynolds, A. (2020). The IMF's Destructive Recipe: Rising Tax Rates and Falling Currencies. Money and the Nation State: The Financial Revolution, Government and the World Monetary System.

Ruzita Abdul Rahim, Rafidah Othman, \& Ling Pick Soon. (2017). Carhart and Q-factor views of mutual fund performance. Jurnal Pengurusan, 51, $261-271$

Shahrin Saaid Shaharuddin, Wee-Yeap Lau, \& Rubi Ahmad. (2018). Is the Fama french three-factor model relevant? Evidence from Islamic unit trust funds. Journal of Asian Finance, Economics and Business, 5(4), 21-34.

Sharpe, W.F. (1966). Mutual fund performance. The Journal of business, 39(1), 119-138.

Tan Boon Pin, Nik Maheran Nik Muhammad, \& Noraani Mustapha. (2017). Inferring the behaviour in choice of unit trust fund. The International Journal of Social Sciences and Humanities Invention, 4(4), 3414-3419

Teoh, T. T. (2012). The Impact of Unit Trust Management Company Fund Investment on Investors' Risk. AJBA, 5(1), 27-54.

The Star (2015). Malaysia's participation in TPP in its national interest, says study. Accessed from https://www.thestar.com.my/business/business-news/2015/12/03/malaysiaparticipation-in-tpp-in-its-national-interest/?style=biz

Treynor, J. (1965). How to rate management of investment funds.

Wan Shahidah W. Mohammed. (2013). Macroeconomic fundamentals and unit trust investment in Malaysia. World Applied Sciences Journal, (Enhancing Emerging Market Competitiveness in the Global Economy), 23, 53-56.

Wilson, J.D. (2015). Mega-regional trade deals in the Asia-Pacific: Choosing between the TPP and RCEP? Journal of Contemporary Asia, 45(2), 345-353.

Woodsome, J. (2016) Malaysia's CAPITAL MARKET MASTERPLAN, 2000-2010: A case study. Working paper in View Points: Center for Financial Markets Milken Institute. Accessed from https://milkeninstitute.org/sites/default/files/reports-pdf/Malaysia-CaseStudy-FORMATTED.pdf

Xiao, Y. (2015). Competitive Mega-regional Trade Agreements: Regional Comprehensive Economic Partnership (RCEP) vs. Trans-Pacific Partnership (TPP). 
Zulkefly Abdul Karim, Nur Hidayah Ramli, Norlin Khalid. (2016). Penentu aliran pelaburan portfolio asing di Malaysia: Suatu kajian panel ARDL. Jurnal Ekonomi Malaysia, 50(1), 3-14. 